\title{
THE EFFECTIVENESS OF ANTI-CORRUPTION EDUCATION COMMUNICATIONS IN ISLAMIC RELIGIOUS EDUCATION AND ITS IMPLEMENTATION IN LEARNING
}

\author{
Muhtadin* \\ Faculty of Communication Science, Universitas Prof. Dr. Moestopo (Beragama) \\ *Correspondence: muhtadin@dsn.moestopo.ac.id
}

\begin{tabular}{|c|c|}
\hline ARTICLE INFO & ABSTRACT \\
\hline $\begin{array}{l}\text { Article History: } \\
\text { received: } 04 / 11 / 2020 \\
\text { revised: } 29 / 11 / 2020 \\
\text { accepted: } 12 / 01 / 2021\end{array}$ & $\begin{array}{l}\text { The background of this research is an attempted to participate in } \\
\text { education for eradicating the corruption behavior. In this } \\
\text { attempted, it is necessary to inculcate anti-corruption values that } \\
\text { are integrated into existing subjects, so they are not burdensome to } \\
\text { emerge new subjects. Furthermore, to provide this education, an }\end{array}$ \\
\hline $\begin{array}{l}\text { Keywords: } \\
\text { Communication Effectiveness; } \\
\text { Anti-Corruption Values; } \\
\text { Islamic Education. }\end{array}$ & $\begin{array}{l}\text { effective learning process is needed by using the right } \\
\text { communication process so that the cultivation of anti-corruption } \\
\text { values can be implemented optimally. This study aims to reveal the } \\
\text { anti-corruption values contained in Islamic Education textbooks } \\
\text { and then provide an overview of how to build effective }\end{array}$ \\
\hline DOI: & $\begin{array}{l}\text { communication to be used in learning. This research is a library } \\
\text { research with student textbooks as the object of study. The results } \\
\text { showed: the values of anti-corruption education contained in the } \\
\text { textbook of Islamic Religious Education and Character are the } \\
\text { values of honesty, caring, independence, discipline, responsibility, } \\
\text { hard work, simplicity, courage, and justice. Effective communication } \\
\text { occurs when paying attention to at least five things: clarity of } \\
\text { material, accuracy of language use, material context, } \\
\text { communication flow, and the environmental culture of students. }\end{array}$ \\
\hline
\end{tabular}

\section{INTRODUCTION}

Corruption now has been categorized as a global problem by the United Nations (Rosikah,2016). The 2020 Global Corruption Barometer Asia report arranged by Transparency International shows that based on a 2019-2020 survey in 17 Asian countries it is illustrated that 3 out of 4 people think that corruption is a big problem for their country. Even 1 of 5 population who access public services such as education and health admit to have paid bribes in the same year. On the other hand, positively, the results of the same survey show that 3 out of 5 residents think that society can play a role in helping reduce corruption. This shows that the public still has optimism to participate in fighting corruption.

One form of corruption prevention in society is through education on anticorruption materials from an early age. According to Dirwan (2019) and Dridi (2014), prevention of corruption through education is an important solution in fighting corruption. Dridi (2014) found that access to education has a correlation with the level of corruption. This illustrates that education will greatly determine the level of corruption, both in terms of reducing or increasing corruption.

By understanding the important role of education in preventing corruption, it is 
appropriate for anti-corruption education material to be embedded in formal education from an early age. According to Pritaningtias et al (2019), the younger generation is an important target of anticorruption education considering its position as agents of change for their generation. According to Sarmini (2017), Indawati (2015), anti-corruption education materials are very effective to be implemented by elementary school teachers. This suggests that anti-corruption education in formal education can be implemented as part of efforts to prevent corruption.

One of the spaces to instill anticorruption education is in Islamic religious education. According to Hadziq (2017), Islamic religious education materials in schools can play an important role in fighting corruption by integrating contextual material for Islamic religious learning with anti-corruption messages.

Islamic religious subjects are very close to instilling the values and character of students. One element that plays an important role in the learning process of anti-corruption character values in Islamic religious subjects is the existence of learning resources or textbooks used. Each taught chapter contains attitudes and values that must be imitated by students and intersect with the values that exist in anti-corruption education.

This study aims to determine how to apply the values of anti-corruption education effectively through learning materials or textbooks of Islamic Religious Education and Characteristics to students.

\section{METHOD}

Every research must use a certain paradigm that is used as a research lens. In this study, the authors used the positivism paradigm. This paradigm holds that reality is in reality and operates in accordance with natural laws. Research tries to reveal the truth of the existing reality and how that reality actually works. The social facts in question include language, legal systems, politics and education. In this case, the paradigm is used to reveal how anticorruption education is embedded in Islamic Religious Education learning and how effective communication can be built in learning.

This research is a research library research, namely the results of literature search are used as the main foundation of the whole research. (Mestika Zed, 2004: 12 ). The object of study is teaching materials from the subject of Islamic Religious Education in the form of a Student Book for Class X Islamic Religious Education and Characteristics for SMA / SMK Class X written by Endi Suhendi Zen and published in Jakarta by the Ministry of Education and Culture in 2016 as teaching material for the 2013 curriculum learning. .

This research is also included in the type of qualitative research, where the interview, observation, and documentation methods are used to examine the implementation of Islamic Religious Education and Character Education in which anti-corruption education is inserted. And the analytical method used is reduction, presentation, and conclusion.

\section{RESULT AND DISCUSSION}

The Role of Islamic Religious Education in Anti-Corruption Education

\section{Anti-Corruption Values in an Islamic Perspective}

Internal anti-corruption education is strongly influenced by the values of anticorruption that are embedded in a person. According to Mukodi (2017), there are nine anti-corruption values that can be understood and practiced, first about honesty, secondly related to caring, third independence, four discipline, five responsibilities, six hard work, seven simplicity, eight about courage, and finally related with justice.

If you look at the history of Islam, corruption during the time of the Prophet Muhammad had occurred, including the story narrated by Imam Bukhori, from Abdullah ibn Amr ra, he said: "There was a person named Karkirah who was the carrier 
of the Prophet's goods, he died in the last battle. The Prophet said: "he will go to hell". Then the friends examined him and found a piece of clothing that he had corrupted from ghonimah ". (Narrated by Al Bukhori)

Karkirah was someone who liked to carry the Prophet's items when the war broke out. When Karkirah died, the Prophet then sentenced her to hell, even the Prophet was reluctant to pray for her. This is based on his behavior which has hidden a ghonimah garment that has not been divided into parts. (Birahmat, 2018)

In the Al-Qur'an there is no clear mention of the term corruption, but there are several verses that allude to this, one of them is Surah Ali Imran verse 161, which means: "it is impossible for a Prophet to betray the spoils of war. Whoever is betrayed in the affairs of the booty, then on the Day of Resurrection he will come with what is betrayed, then each self will be given retribution for what he did with (retribution) in kind, while they are not being persecuted."

The explanation of this verse is the term ghulul which means betrayal. According to Al Maraghi, he explained that the word ghulul in this verse means taking something secretly, for example stealing something. Rasulullah himself expanded the meaning of ghulul into two forms, namely Commission and Gifts. Commission is an act of taking something other than the salary that has been given. In this case the Prophet said: "whoever we hire to become an employee at a job then we set a certain salary for him, then what he collects after that is cheating (corruption). (Narrated by Abu Daud). While a gift is defined as a gift that a person gets because of the position that is attached to him. In this regard too, the Prophet said: "The reward that officials receive is corruption (ghulu)". (HR. Ahmad). (Birahmat, 2018)

With this explanation, it should be used as an afterthought and a strong basis for action to take an effort to eliminate corrupt behavior. Commissions and prizes are actually things that are commonplace in everyday life. However, if these two things are done by individuals who are bound in a certain position, then commissions and rewards can be the things that drag the person into the crime of corruption. So it is very important to carry out education that provides knowledge about how to prevent things that can be done so as not to get caught in the cycle of corruption.

\section{Islamic Regional Education and Cultivation of Anti-Corruption Values}

Islamic Religious Education and Character is education that provides knowledge and skills, and shapes the personality attitudes of students in practicing Islamic teachings (Kemendikbud RI, 2014). In more detail, Minarti (2013) describes that Islamic Education is a complete system with epistemic systematics consisting of interconnected theory, practice, method, value, and organization through harmonious cooperation in the Islamic conception of Allah, the universe. , humans, and society.

Meanwhile, Zakiah Daradjat (1998) views that Islamic religious education is education through the teachings of the Islamic religion, namely in the form of guidance and care for students so that later after completing education they can understand, appreciate, and practice the teachings of Islam that have been he believed in a comprehensive manner, and made the teachings of Islam as a view of his life for the safety and welfare of life in the world and the hereafter.

Based on the understanding of the Ministry of Education and Culture (2014), Minarti (2013), and Zakiah Daradjat (1998) above, it can be understood that Islamic religious education is education that provides knowledge and skills, and shapes the personality attitudes of students in practicing Islamic teachings and making Islamic teachings. it is a guideline in his view of life. This illustrates that Islamic religious education provides a very appropriate space for anti-corruption education from an early age. 
Based on Frimayanti's research (2017), the concept of anti-corruption education needs to be emphasized on students from an early age by getting used to an anti-corruption life, through the introduction of an anti-corruption lifestyle, due to corruption, and the inculcation of religious values into students. The implication of the existence of anticorruption education in Islamic religious education is the need for curriculum adjustments that must be linked to all subjects on anti-corruption values.

However, adjusting the curriculum, especially in terms of Islamic religious education, is not easy. According to the results of research conducted by Fadhil (2019) regarding efforts to implement anticorruption values in Islamic Aama Education, it can be concluded that the current Islamic Religious Education model is still limited to a dogmatic concept, so it is still trapped in structural forms. Islamic Religious Education has not functionally explored its ability to internalize anticorruption values. Therefore, if anticorruption values are to be applied in Islamic Religious Education, it is necessary to transform learning models for students that not only build individual morality but also public morality.

\section{Effective Communication in Inculcating Anti-Corruption Values in Learning Materials}

Research conducted by Nisa (2016) describes several things related to how to build effective communication in character education efforts. Communication becomes a system in the character education process. Effective communication has terms, conditions, principles and strategies, all of which lie in the quality of the educator in placing his / her function and responsibility as an educator. The description of Nisa's (2016) research results affirms the importance of effective forms of communication by educators in building the character of students, including in terms of internalizing anti-corruption values.
Research conducted by Yossita Wisman with the title Effective Communication in the World of Education. (Wisman, 2017) the focus of this research is to explore appropriate methods in educational communication, strategies to improve communication effectiveness in education, and to understand barriers to educational communication. This research then concludes that the appropriate method of educational communication is direct or indirect communication adapted to the situation and conditions. Strategies for increasing the effectiveness of communication in education are to identify communication goals, choose the right communication media, assess the purpose of messages, and maximize the role of the communicator. Barriers to communication, among others, obstacles in the process, physical barriers, semantic and psychological.

The research that the researchers found did discuss a lot about Effective Communication and Anti-Corruption Education, but researchers have not found research that focuses on Effective Communication on Anti-Corruption Education in Islamic Religious Education and Its Implementation in Learning. This is what distinguishes the research that the author has made from previous research.

\section{The Role of Islamic Religious Education Textbooks as Anti-Corruption Learning Media}

According to Arif (1997) textbooks are a source and media that can be used in the learning process. Books as materials or as learning media have many advantages, including being able to be actively used to help the learning process of students independently, textbooks are easier to carry, books can contain a wider field of knowledge and can keep up with the times. Textbooks that are in the good category must have an educational function for their readers.

The criteria for educational textbooks are the first to have actual information, the second to show a high level of relevance to 
curriculum guidance, the third to have a proportional balance between sections, and the fourth to be able to appear in a language that the reader can understand (Suyanto, 2000). It can be said that a good textbook is a textbook that can be a source for students to be able to stimulate their thought processes in order to find out actual information so that in life they can solve existing problems with the skills and knowledge they already have.

If the description above is applied in an effort to instill anti-corruption education in Islamic religious education teaching materials, a good and effective Islamic religious education textbook is a textbook that is able to stimulate the thinking process of students so that from the start they are able to understand anti-corruption attitudes as a required character. himself.

\section{Discussion}

Based on the analysis carried out on the Islamic Education and Character Education textbook class X SMA / SMK curriculum 2013, there are many main subjects in the book that are related to the values of anti-corruption education, namely honesty, caring, independence, discipline, responsibility, hard work, simplicity, courage, and lastly are related to justice.

Furthermore, in an effort to provide anti-corruption education through Islamic Religious Education, the learning process must be effective and successful. In an effort to provide effective learning, effective communication must also be used in providing this material in learning. Effective communication can be done and implemented in at least five ways: a) Clarity; In the learning process of Islamic Religious Education in which anti-corruption education is inserted, it is required to use easy communication language, and package the learning information in detail about how the relationship between Islamic Religious Education material being taught with anticorruption values, so that the material will be accepted and understood by students will be easily accepted. b) Accuracy; The accuracy of the material content that will be given in relation to anti-corruption education in learning Islamic Religious Education needs to be considered. The teacher must prepare any material content that will be presented in the classroom in relation to the inculcation of anti-corruption values. In addition, the language used must be the right language and not use languages that have multiple interpretations. c) Context; the point is that the language and information conveyed must be in accordance with the circumstances and environment in which the communication occurs. When the learning process occurs, the context of the material is adjusted to the learning environment. For example, the packaging of material intended for class $\mathrm{X}$ students will have different approaches in terms of language and context with class XI students, as well as the context of the material for class XI students will be different from students in class XII. d) Flow; language and information to be presented must be structured in a clear flow or systematics, so that the party receiving the information can be quick and responsive and enthusiastic. This is where the role of the Learning Implementation Plan (RPP) in regulating the structure of the implementation of learning so that in the process of exchanging information about anti-corruption education in Islamic Religious Education learning in the classroom, it has a clear and unambiguous flow. e) Culture; In communicating, they must adapt to the culture of the individuals who are invited to communicate, when students have the habit of communicating with verbal language, learning must be adapted to the cultural conditions that occur in the classroom, and when students tend to be more able to understand using nonverbal language, the teacher must be able to customize it.

With the five things mentioned above, the implementation of Islamic Religious Education learning in which anti-corruption values are inserted can run well. If the five steps of effective communication above are carried out in learning, it is not impossible 
that students will be interested because the communication built is based on the clarity of the material, the accuracy of the content, the adjustment of the context, the regular learning flow using the Learning Implementation Plan (RPP), and adapting to the communication culture. students in learning so that learning will run effectively.

\section{CONCLUSION}

The findings that are expected to be obtained in this journal are how the nine anti-corruption values (honesty, caring, independence, discipline, responsibility, hard work, simplicity, courage, and justice) can be integrated into Islamic Religious Education and Character learning.

Based on the findings, information was also obtained that the nine anticorruption values contained in the material of Islamic Religious Education and Character Class X SMA / SMK can be implanted into students through the learning process of Islamic Religious Education so that it does not need to be a separate separate subject.

In an effort to instill the nine values of anti-corruption education in the textbook, several things are needed or risk mitigation of effective communication between educators and students so that good information exchange occurs.

In order for anti-corruption learning materials to be implanted properly in participants, there are at least 5 things that still need attention, including: 1 ) the content of learning materials in textbooks must have material clarity, where the material is delivered in easy but detailed language so that the material can be accepted well; 2) the accuracy of the material content must be ready and not multiple interpretations, in this case the role of the teacher is also important so that the content of textbook materials can be conveyed with the same interpretation; 3) the context of the information on anti-corruption material presented in the book must be easily adjusted by the teacher to the circumstances and environment around the students. 4) The language flow that is conveyed in the textbook must be clear and not confused. 5) The textbook must be able to make it easy for the teacher to adjust it according to the culture in the classroom.

\section{REFERENCE}

Abdullah Hadziq Arif (2017) Zainudin dkk, (1997). Pedoman Baru Menyusun Bahan Ajar, Jakarta: Gramedia.

Birahmat, Budi, (2018). "Korupsi dalam Perspektif Al Qir'an”, Jurnal IAIN Curup,3(1),http://journal.iaincurup.a c.id/index.php/JF/article/download/ 457

Darajat, Zakiyah, (1998). Ilmu Pendidikan Islam, Jakarta: Bumi Aksara.

Dridi, Mohamed (2014), "Corruption and Education: Empirical Evidence", dalam International Journal of Economics and Financial Issues Vol. 4, No. 3, 2014, pp.476-493.

Effendi, Onong Uchjana, (2004). Dinamika Komunikasi, Bandung: Remaja Rosdakarya.

Effendi, Onong Uchjana, (2005). Ilmu Komunikasi: Teori dan Praktek, Bandung: Remaja Rosdakarya.

Dirwan, Ahmad, ]](2019, The Effect of Education Against Corruption in Indonesia, OIDA International Journal of Sustainable Development Vol. 12 No. 01 pp. 53-64

Fadhil, Moh., (2019). "Pendidikan Agama Islam, Internalisasi Nilai-Nilai Anti Korupsi dan Pencegahan Tindak Pidana Korupsi", Jurnal JRTIE, 2 (1), http://jurnaliainpontianak.or.id/inde x.php/irtie/article/view/1229/628

Frimayanti, Ade Imelda, (2017) "Pendidikan Anti Korupsi Dalam Pendidikan Agama Islam", Jurnal Al Tadzkiyah dalam Moraref, 8 (1), https://www.researchgate.net/public ation/330518887 Pendidikan Anti K orupsi Dalam Pendidikan Agama Isla $\underline{m}$

Indawati, Ninik, (2015), “The Development of Anti-Corruption Education Course for Primary School Teacher Education 
Students"; dalam Journal of Education and Practice Vol.6, No.35, 2015.

Minarti, Sri, (2003). Ilmu Pendidikan Islam: Fakta Teoritis-Filosofis dan AplikatifNormatif, Jakarta: Amzah.

Moleong, Lexy J., (2002). Metodologi Penelitian Kualitatif, Bandung: Remaja Rosydakarya.

Mukodi, (2017). Model Penyadaran Anti Korupsi: redesain konseptual dan aplikatif melalui teenager corruption wacth, Pacitan: LPPM Press STKIP PGRI.

Hadziq, Abdulloh (2017), "Konsepsi Pendidikan Agama Anti Korupsi di Sekolah Dasar" dalam Elementary Islamic Teacher Journal Vol. 5 / No. 2 / Juli-Desember 2017

Nisa, Hoirun, (2016). Komunikasi yang Efektif dalam Pendidikan Karakter, Jurnal Universum, $10 \quad$ (1) https://jurnal.iainkediri.ac.id/index.p hp/universum.

Pedoman Mata Pelajaran Sekolah Menengah Atas/Madrasah Aliyah dalam peraturan Menteri Pendidikan dan Kebudayaan Nomor 59 Tahun 2014 tentang Kurikulum 2013 Sekolah Menengah Atas/Madrasah Aliyah, Jakarta: Kemendikbud RI, 2014.

Pritaningtias, D.W., Barendriyas, A.S., Sabela, A.R., \& Utari, I.S. (2019) 'Implementation of Anti - Corruption Education through PENETRASI (Penanaman Sembilan Nilai Karakter Anti Korupsi) Method for the Urban Village Community of Jabungan.' Indonesian Journal of Advocacy and Legal Services, 1(1).

Rosikah, Catrina Darul, (2016). Pendidikan Anti Korupsi: kajian anti korupsi teori dan praktik, Jakarta: Sinar Grafika.

Sarmini et al, (2018), "The importance of anti corruption education teaching materials for the young generation" dalam J. Phys.: Conf. Ser. 953012167

Sugiono, (2009). Memahami Penelitian Kualitatif, Bandung: Alfabeta.

Suyanto, (2000). Refleksi dan Reformasi Pendidikan Di Indonesia Memasuki
Milenium III, Yogyakarta: Adicita Karya Nusa.

Transparansi Internasional, 2020, Laporan Global Corruption Barometer Asia 2020: Citizen'Views and Experiences of Corruption, Transparency International.

Wisman, Yossita, (2017). "Komunikasi Efektif dalam Dunia Pendidikan", Jurnal Nomosleca, 3 http://jurnal.unmer.ac.id/index.php/ n/article/view/2039.

Zed, Mestika, (2004). Metode Penellitian Kepustakaan, Jakarta: Yayasan Obor Indonesia.

Zen, Endi Suhendi, (2016), Buku Siswa Pendidikan Agama Islam dan Budi Pekerti SMA/SMK Kelas X, Jakarta, Kemendikbud 